\title{
Shareholder Remedies: Demise of the Derivative Claim?
}

\author{
Julia Tang*
}

\begin{abstract}
The new statutory derivative claim in the Companies Act 2006 ("CA 2006") was meant to herald a more modern, flexible and accessible criteria for determining whether a shareholder could pursue an action. It was aimed at tackling the problematic rules which emerged from Foss $v$ Harbottle (1843). This paper examines the twostage procedure in the CA 2006 Part 11 by focusing on specific elements within it, i.e., prima facie case, ratification etc. The complexities of pursuing a statutory derivative claim will be highlighted by critically discussing how these elements have been interpreted in recent case law such as Franbar Holdings Ltd v Patel (2008) and Stainer $v$ Lee (2010). It will be argued that the uncertainty that presently plagues the two-stage procedure and the interpretation of the elements within it is likely to lead to the demise of the statutory derivative claim in England and Wales for the foreseeable future.
\end{abstract}

\section{A. INTRODUCTION}

Obscure, complex, rigid, old-fashioned and unwieldy are terms which have all been used to describe the rule in Foss $v$ Harbottle. ${ }^{1}$ This prompted the Law Commission of the United Kingdom to recommend 'that there should be a new derivative procedure with more modern, flexible and accessible criteria for determining whether a shareholder can pursue the action. ${ }^{2}$ This paper analyses the new statutory derivative claim in the Companies Act 2006 ("CA 2006") Part 11 by examining the twostage procedure. Considering the breadth of the two-stage procedure, this paper shall be focusing only on the prima facie case, section 172 (duty to promote the success of the company) within sections 263(2)(a) and 263(3)(b), the applicant's good faith and ratification. Key cases such as Stainer v Lee, ${ }^{3}$ Mission Capital plc v Sinclair ${ }^{4}$ and Franbar Holdings Ltd $v$ Patel $^{5}$ will help to shed light on how courts are construing these matters

\footnotetext{
* The author would like to thank Professor John Lowry, University College London for his valuable comments and input on earlier drafts of this paper. Any errors or omissions are the author's sole responsibility.

(1843) 2 Hare 461, 67 ER 189.

2 Law Commission, Shareholder Remedies: Report on a Reference under Section 3(1)(e) of the Law Commissions Act 1965 (Law Com No. 246, 1997) para 6.15.

3 [2010] EWHC $1539(\mathrm{Ch})$, [2011] BCC 134.

4 [2008] EWHC1339(Ch), [2008] BCC 866.

5 [2008] EWHC $1534(\mathrm{Ch})$, [2008] BCC 885.
} 
in practice. Before proceeding with an analysis of the list of issues above, any analysis of Part 11 would be remiss without a brief overview of Foss $v$ Harbottle. The paper also examines the judiciary's stance to indemnity costs orders in the new regime and analyses whether such orders provide the answer for shareholders' financial worries in pursuing a derivative claim. Additionally, the paper will analyse the potential of obtaining corporate relief in an unfair prejudice petition in light of Clark $v$ Cutland ${ }^{6}$ and Gamlestaden Fastigheter AB v Baltic Partners Ltd. ${ }^{7}$ Finally, by drawing together all the issues above, a conclusion will be made as to the likely future for the new statutory derivative claim.

\section{B. BRIEF OVERVIEW OF FoSS V HARBotTLE}

The two overarching rules of Foss $v$ Harbottle are the 'proper plaintiff' and the 'internal management' rules. The 'proper plaintiff' rule states that the appropriate person to bring a claim for wrongs done to a company is the company itself. This rule has strong ties to the separate legal personality doctrine where the company is viewed as a legal entity separate and distinct from its members. It was stated by Lord Halsbury LC in the seminal case of Salomon $v$ Salomon \& Co Ltd 'that once the company is legally incorporated it must be treated like any other independent person with its rights and liabilities appropriate to itself ... .'9 What is apparent from this statement is that the company's rights and liabilities are reserved to the company itself; it is generally for the company to pursue its rights and settle its liabilities. Furthermore, in Edwards v Halliwell, ${ }^{10}$ Jenkins LJ affirmed that "the proper plaintiff in an action in respect of a wrong alleged to be done to a company or association of persons is prima facie the company or the association of persons itself.' ${ }^{11}$ The 'internal management' rule itself is closely linked to the 'majority rule' where it is generally accepted that the courts will not interfere with the commercial decisions of management. This is because

\footnotetext{
[2003] EWCA Civ 810, [2004] 1 WLR 783.

[2007] UKPC 26, [2007] Bus LR 1521.

8 [1897] AC $22(\mathrm{HL})$.

9 ibid 30.

10 [1950] 2 All ER 1064.

11 ibid 1066.
} 
shareholders are believed to be better placed to adjudicate internal issues within the company. The oft-quoted phrase is that ' $[\mathrm{t}]$ his Court is not to be required on every Occasion to take the Management of every Playhouse and Brewhouse in the Kingdom'. ${ }^{12}$

How then would an individual shareholder be able to pursue a claim to redress a wrong done to the company? The answer lies in the exceptions to Foss $v$ Harbottle. The 'fraud on the minority' exception enabled an individual shareholder to pursue a claim belonging to the company but in the shareholder's own name and obtain a corporate remedy. To satisfy this exception, the wrongdoing had to amount to 'fraud' and the wrongdoers must have been in control of the company. An aggrieved minority shareholder would now be allowed to bring an action on behalf of themselves and others, which in usual circumstances would be blocked by the wrongdoers in control. ${ }^{13}$ These requirements seem on the surface to be easily satisfied. However, the truth was that the law relating to the rules in Foss $v$ Harbottle and the exceptions was really only accessible by specialist practitioners as it was essential to analyse case law spanning a 150 years. ${ }^{14}$ Furthermore, restrictive judicial attitudes made it questionable as to whether the courts were capable of developing a coherent set of legal principles that would strike the proper balance between the competing goals of enhancing 'shareholder confidence' and not imposing 'significant burdens on management." ${ }^{15}$ This meant there was no coherent principle underlying the rules and exceptions, which made it difficult for lawyers let alone a shareholder layperson to build a strong derivative claim.

\section{Two-stage Procedure}

The two-stage procedure during the permission stage involves firstly (i) the court considering whether a prima facie case has been satisfied; and (ii)

${ }^{12}$ Carlen v Drury (1812) 1 V \& B 154, 158; 35 ER 61, 63 (Lord Eldon LC).

13 Edwards v Halliwell [1950] 2 All ER 1064, 1067.

14 Law Commission, Shareholder Remedies, (Law Com No. 246, 1997) para 1.4.

15 Law Commission, Shareholder Remedies: A Consultation Paper (Law Com No. 142, 1996) para 1.13; Brian R. Cheffins, 'Reforming the Derivative Action: The Canadian Experience and British Prospects' (1997) 2 Company, Financial and Insolvency Law Review 227, 233. 
if a prima facie case is shown the court may require that evidence be provided by the company. If the prima facie case is not satisfied, the court must dismiss the case. The second stage involves the courts considering the list of factors under CA 2006 ss. 263(2) and (3). Section 263(2) is of a mandatory nature, while section 263(3) is discretionary. Judicial discretion remains a significant and decisive part of the statutory derivative claim as the courts wield considerable control through their interpretation of the above factors. A troubling aspect about the list of factors in s. 263(3) is their open-ended nature since they were intended by the Law Commission to be non-exhaustive. Their limitless nature renders them inherently uncertain. While practitioners struggle with the explicitly stated factors in ss. 263(2) and 263(3), s. 263(3) is seemingly expandable by the courts. At the moment when practitioners understand the application of a particular factor, another one appears for them to contend with. The Law Commission responded to concerns about the ambiguity of these non-exhaustive factors by stating that an additional specific list of factors together with developing case law would assist practitioners in advising their clients. ${ }^{16}$ This will undoubtedly be of great assistance but there remains a long wait for a burgeoning body of case law.

\section{Prima Facie Case}

The court must dismiss the application if the supporting evidence filed by the applicant does not disclose a prima facie case for giving permission. ${ }^{17}$ This stage was not recommended by the Law Commission since their view was that including an express test on the merits could easily result in a time consuming and expensive mini-trial. ${ }^{18}$ The prima facie case was only subsequently included by Parliament. It was believed that an adequate front-line safeguard should be in place for derivative claims to 'avoid opening a Pandora's Box to every disenchanted individual in the country. ${ }^{19}$ The fear that the breadth of the new statutory derivative claim, and the removal of 'fraud on the minority' and 'wrongdoer control' would open the floodgates prompted this last minute addition. Parliament's

\footnotetext{
${ }^{16}$ Law Com No. 246 (n 2) para 6.73.

17 Companies Act 2006, s. 261(2).

18 Law Com No. 246 (n 2) para 6.71.

19 HL Deb 9 May 2006, vol 681, col 885 (Lord Sharman).
} 
intention was that the courts should be able to dismiss frivolous claims without the involvement of companies and at the earliest possible opportunity. ${ }^{20}$ Although well-intentioned on their part, this was a failure to foresee that requiring applicant shareholders to fulfil a prima facie case at an early stage can often be onerous because of information asymmetries. Furthermore, derivative claims are heavily based on factual disputes and courts may be lured into the trap of carrying out mini-trials at this juncture. We should however be more confident of the ability of judges in approaching the prima facie case since Cheffins suggests that permission hearings can be carried out expeditiously so long as judges refrain from enforcing a heavy burden of proof on applicants. ${ }^{21}$ Regardless of whether judges impose a heavy burden of proof, it is the applicant's supporting evidence that is crucial in the prima facie case. One suspects that judges will continue to be inundated with bundles of pleadings and evidentiary documents to disclose a prima facie case.

What does prima facie mean? This test is familiar to practitioners as it had been the primary test in interim injunction applications. ${ }^{22}$ But establishing the probability of success is not clear-cut. Gibbs suggests that satisfying the prima facie case requires merely establishing more than a 0 per cent chance of success, ${ }^{23}$ which is derived from the Australian courts' approach in Australian Broadcasting Corporation v Lenah Game Meats Pty $\mathrm{Ltd}^{24}$ and is in turn taken from American Cyanamid Co $v$ Ethicon $L t d{ }^{25}$ With respect I fail to see where the 0 per cent chance of success is derived from. It was clearly stated in American Cyanamid that the courts must be satisfied that there is a serious question to be tried, and fettering the court's discretion by a technical rule based on whether the plaintiff's success lay above or below the 50 per cent mark was thought to be

20 ibid col 883 (Lord Goldsmith).

21 Cheffins (n15) 245.

22 Andrew Keay and Joan Loughrey, 'Something Old, Something New, Something Borrowed: an Analysis of the New Derivative Action under the Companies Act 2006' (2008) 124 Law Quarterly Review 469, 480.

23 David Gibbs, 'Has the Statutory Derivative Fulfilled its Objectives? A Prima Facie Case and the Mandatory Bar: Part 1' (2011) 32 Company Lawyer 41, 42.

24 [2001] HCA 63, (2001) 208 CLR 199 (High Court of Australia).

25 [1975] AC 396 (HL). 
inappropriate. ${ }^{26}$ This means that rigid, mechanistic calculations should be avoided. 'Serious question to be tried' provides a more realistic assessment of whether a case should proceed. However, caution is adopted to ensure that the merits of the proposed derivative claim are not generally entered into. ${ }^{27}$ This is to avoid the first stage being turned into a drawn out process. Under common law in Prudential Assurance Co Ltd v Newman Industries (No. 2), ${ }^{28}$ the Court of Appeal stated that the plaintiff ought to establish a prima facie case '(i) that the company is entitled to the relief claimed, and (ii) that the action falls within the proper boundaries of the exception to the rule in Foss $v$ Harbottle. ${ }^{29}$ Under Part 11 , there will no longer be any requirement to satisfy the exception to the rule. What can be gleaned from the above statement is that an applicant has to establish a good cause of action that should be tried. Perhaps all that is required is to demonstrate: a credible case; a substantive claim; a genuine triable issue; or that the case is worthy of being heard in full. ${ }^{30}$ With such varying thresholds the prima facie case is still decidedly difficult to pinpoint. However, whether the test follows that under interim injunction applications or common law, it is clear that prima facie is not a foreign concept. Precedents will build a clearer picture for practitioners in understanding this test although trawling through case law is admittedly undesirable.

Some commentators have remarked that the judiciary's approach to the prima facie case might be to allow the claim to go through to the second stage should there be something in the claim ${ }^{31}$ since it would still be possible to stop proceedings at that stage. ${ }^{32}$ If this is truly borne out by the courts, the prima facie case is in reality redundant and unnecessary. Significant time and resources would be squandered on this first stage

\footnotetext{
26 ibid 406-07.

27 Swansson v R A Pratt Properties Pty Ltd [2002] NSWSC 583 [25].

28 [1982] Ch 204 (CA).

29 ibid 222.

30 Keay and Loughrey (n 22) 484.

31 Simon James, 'The Curse of Uncertain Times' (2007) 8 Journal of International Banking and Financial Law 447, 448.

32 Brenda Hannigan and Dan Prentice, Hannigan and Prentice: The Companies Act 2006 - A Commentary (LexisNexis Butterworths 2007) para 4.46.
} 
since the rationale underlying its existence ie a screening mechanism could as easily be achieved in the second stage.

Recent cases dealing with the prima facie case will now be examined. In Iesini $v$ Westrip Holdings Ltd, ${ }^{33}$ Lewison J noted that the judge at first instance had considered there was a prima facie case on paper and with that moved on to the second stage. The only explanation provided by Lewison J was that: $:^{34}$

At the first stage, the applicant is required to make a prima facie case for permission to continue a derivative claim, and the court considers the question on the basis of the evidence filed by the applicant only, without requiring evidence from the defendant or the company. The court must dismiss the application if the applicant cannot establish a prima facie case.

This is not extremely helpful since this was already apparent from $\mathrm{s}$. 261(2) in any case. However, the fact that Lewison J pointed out that no evidence will be required at this stage from the defendant or the company makes it clear that the prima facie case should not turn into a mini trial of sorts.

In Stimpson v Southern Private Landlords Association ${ }^{35}$ there was no consideration of the first-stage because Judge Pelling QC considered that to be unduly elaborate in the circumstances. He preferred to adopt a fictional approach that the case had been considered at the first stage since this reflected both the procedural and practical reality, and would yield the fair and proper result. ${ }^{36}$ His reasoning is puzzling since no consideration of the prima facie case was conducted either procedurally or in reality. Despite the reasoning this approach is to be welcomed. Whether a company has a good cause of action or serious question to be tried can equally be answered at the second stage during consideration of the long list of factors there. This approach can save applicants incurring unnecessary costs in passing an additional first hurdle. However, this leads to the unsatisfactory result of having a redundant process in the permission stage. That certainly was never Parliament's intention.

\footnotetext{
33 [2009] EWHC $2526(\mathrm{Ch})$, [2010] BCC 420.

34 ibid [78].

35 [2009] EWHC 2072 (Ch), [2010] BCC 387.

36 ibid [3].
} 
In the Scottish case of Wishart $v$ Castlecroft Securities $L t d,{ }^{37}$ their Lordships stated that: ${ }^{38}$

the question is not whether the application and supporting evidence disclose $a$ prima facie case against the defenders in the proposed derivative proceedings, but whether there is no prima facie case disclosed for granting the application for leave... It is to be noted that no onus is placed on the applicant to satisfy the court that there is a prima facie case: rather, the court is to refuse the application if it is satisfied that there is not a prima facie case.

The subtle difference is that the first connotes a positive obligation on the applicant, while the latter indicates that the court is unsatisfied with the supporting evidence disclosing a prima facie case. This means a low threshold is placed on the applicant at this point ${ }^{39}$ because the onus on the applicant has been dispensed in favour of a more judicial discretionary stance. Since Wishart is merely persuasive and not binding on English courts it will be interesting to see whether this approach will be followed by the English courts in the future.

In Mission Capital plc $v$ Sinclair $^{40}$ and Franbar Holdings Ltd $v$ Patel $^{41}$ the two-stage procedure was effectively telescoped into one. In Franbar, counsel for the defendants had accepted that it would be appropriate... to deal with the entirety of the application for permission to continue at a single hearing. ${ }^{42}$ While in Mission Capital the parties agreed to combine the two parts of the process which the judge regarded as 'sensible'. ${ }^{43}$ Would it then not be 'sensible' to embark on the two-stage procedure? This was clearly not the position taken by the judge in Langley Ward Limited $v$ Gareth Wynn Trevor, Seven Holdings Limited ${ }^{44}$ when he expressed his disappointment that the preliminary filter of a prima facie

37 [2009] CSIH 65, 2010 SC 16.

38 ibid [31].

39 Andrew Keay and Joan Loughrey, 'Derivative Proceedings in a Brave New World for Company Management and Shareholders' [2010] Journal of Business Law 151, 155; Daniel Lightman, 'Coming of Age?' (2010) 160 New Law Journal 1750, 1750.

40 [2008] EWHC $1339(\mathrm{Ch})$, [2008] BCC 866.

41 [2008] EWHC $1534(\mathrm{Ch})$, [2008] BCC 885.

42 ibid [24].

43 [2008] EWHC1339 (Ch), [2008] BCC 866 [36].

44 [2011] EWHC 1893 (Ch). 
case had been bypassed entirely, which was an unfortunate distortion of the statutory procedure..$^{45}$ The recent trend is to either bypass the prima facie case proceeding directly to the second stage, or to bundle the twostage procedure into a single hearing.

The prima facie case imposes an unnecessary hurdle for applicants. If the reform aim was to create a 'modern, flexible and accessible criteria', the inclusion of a prima facie case has not assisted in delivering such criteria. An extra hurdle acts as a deterrent for potential applicants. Recent cases have nevertheless shown that the first stage has mostly either been bypassed or telescoped. The courts have also construed the prima facie case leniently. In a table of six cases dealing with prima facie decisions which were examined by Gibbs, ${ }^{46}$ all passed the threshold test. This is a reminder that the first hurdle will likely be the easier one to overcome as a whole. Thus, lawyers and applicants may be comforted to know that the prima facie case is hardly an obstacle. They can now focus their attentions on the second stage which will likely be determinative in the granting of permission. It is increasingly likely that the first stage will be ignored in future cases to the great relief of applicants but heavy sigh of defendants.

\section{Section 172 (Duty to Promote the Success of the Company)}

Section 172 is a new statutory provision, embodying the concept of 'enlightened shareholder value', whose precise meaning is unclear. The reference to s. 172 twice under ss. 263(2)(a) and 263(3)(b) stresses its importance. Linking Part 11 to directors' duties was always going to be complicated because the codification of directors' duties has not eliminated the need to refer to past case law. There is ambiguity surrounding the importance of common law rules or equitable principles in interpreting s. 172. This uncertainty may have a spillover effect in terms of construing s. 172 during the permission stage. Do the decisions of directors, in light of the business judgement rule, remain centre stage in the interpretation of $\mathrm{s} .172 ?^{47}$ If it is, this can "operate to abrogate the

\footnotetext{
45 ibid [6]-[7].

46 Gibbs (n 23) 43.

47 Joseph Lee, 'Shareholders' Derivative Claims under the Companies Act 2006: Market Mechanism or Asymmetric Paternalism?' (2007) 18 International Company and Commercial Law Review 378, 380.
} 
court's discretion in favour of that of the company's management, who could effectively scupper any derivative claim. ${ }^{48}$ This statement alludes to concerns that deferring to the judgment of company's management will hinder the pursuance of derivative claims. This is because few directors will pursue a derivative claim for reasons such as reputational damage to the company, high financial costs, disruption to management, etc. but will now be able to justify their reasons by reference to their good faith judgment under s. 172. The interpretation of s. 172 ultimately lies with the courts whose role is to exercise tight judicial control. ${ }^{49}$

\section{(a) Section 263(2)(a) - Mandatory Factor}

How have the courts construed s. 172 within s. 263(2)(a)? In Franbar, William Trower QC refused to apply the mandatory bar under s. 263(2)(a). $\mathrm{He}$ was of the opinion that there was "room for more than one view. ${ }^{50} \mathrm{He}$ was sympathetic to the position in which directors often find themselves when deciding whether to pursue a derivative claim. This can be said of most derivative claims as directors are often faced with competing considerations. It is refreshing to see a realistic and empathetic judgment on directors' decision-making in this instance. The approach taken by the judge here was to allow the claim to pass through this hurdle granted there was 'sufficient material for the hypothetical director to conclude that the conduct... had given rise to actionable breaches of duty. ${ }^{51}$ It will be a rare case where the material is so lacking that a hypothetical director would not seek to bring a claim. Therefore, a flexible approach coupled with a minimum of sufficient material suggests a low mandatory threshold to overcome.

Iesini $^{52}$ is significant for clarifying that s. 263(2)(a) applies 'only where the court is satisfied that no director acting in accordance with s.172 would seek to continue the claim,' and '[i]f some directors would, and others would not, seek to continue the claim, the case is one for the

\footnotetext{
48 John Lowry and Arad Reisberg, Pettet's Company Law: Company and Capital Markets Law ( $3^{\text {rd }}$ edn, Pearson Longman 2009) 239.

49 HL Deb 27 February 2006, vol 679, col GC5 (Lord Goldsmith).

50 Franbar [2008] EWHC 1534 (Ch), [2008] BCC 885 [30].

51 ibid.

52 [2009] EWHC 2526 (Ch), [2010] BCC 420.
} 
application of s.263(3)(b). ${ }^{53}$ Both phrases combined indicate a plurality of hypothetical directors, which is confusing since s. 263(2)(a) is expressed as a singular person. This is a precarious situation as the very foundation of s. 172 - the hypothetical director - which is central to the permission stage is tenuous. The courts in future cases are urged to clarify this unfortunate position.

In Stimpson the judge relied heavily on the guidance in Franbar but drew attention to the fact that such a list was not comprehensive. ${ }^{54}$ The list of issues will therefore vary on a case to case basis depending on their own particular factual circumstances. In reality ss. 263(2)(a) and 263(3)(b) are fluid and highly interconnected factors, which is why the issues identified by William Trower QC in Franbar in relation to s. 263(3)(b) were considered under the mandatory bar of s. 263(2)(a) in that case. Stimpson also indicates that a balancing exercise is required when dealing with competing objectives in a company with mixed objects. ${ }^{55}$ But it does not go further than this and it is regrettable a more detailed framework was not laid out.

Similarly, in Iesini Lewison J, while examining whether there was a mandatory bar, provided a list of factors which a director acting in accordance with s. 172 would consider such as the size of the claim, cost of proceedings, disruption to the company's activities, company's ability to fund the proceedings etc. ${ }^{56}$ This should prove useful for lawyers and applicants seeking an indication of what the courts will deem important as factors for directors to consider under s. 172. It is envisaged that these factors will be used as a reference by other courts in the future.

In Kiani $v$ Cooper, ${ }^{57}$ Proudman $\mathrm{J}$ found that a director acting in accordance with s. 172 would decide to continue the proceedings, at least down to disclosure, on the basis that there was some strong evidence in favour of the case advanced by the applicant. Furthermore, a hypothetical director would consider the size of the claim, approximately $£ 296,000$, which if successful would ensure full return for all creditors. ${ }^{58}$ Financial

\footnotetext{
53 ibid [86].

${ }^{54}$ [2009] EWHC 2072 (Ch), [2010] BCC 387 [28].

55 ibid [26].

56 [2009] EWHC 2526 (Ch), [2010] BCC 420 [85].

${ }^{57}$ [2010] EWHC 577 (Ch), [2010] BCC 463.

58 ibid [44].
} 
considerations will likely be one of the more important factors a hypothetical director will have regard to. A company's success is usually equated with financial prosperity. But this may not necessarily apply to companies that are non-profit organisations. Courts will have to be privy to this; it will be appropriate to follow the guidance provided in Stimpson. ${ }^{59}$

\section{(b) Section 263(3)(b) - Discretionary Factor}

William Trower QC in Franbar, in considering s. 263(3)(b), stated that a hypothetical director would consider a wide range of factors such as the claim's prospects of success, the ability of the company to make a recovery on any damages award, the disruption to the company, costs of proceedings, and any damage to the company's reputation and business. ${ }^{60}$ It was not these factors that were conclusive in his decision to refuse permission. Instead it was that a hypothetical director would attach little importance to the continuation of the derivative claim since there was an existing, parallel unfair prejudice petition. Keay and Loughrey argue that in Franbar, a director might still consider the continuation of the derivative claim important despite the possibility of a s. 994 petition being settled because of the nature of the remedy obtained. ${ }^{61}$ But they seem to be missing the point that if the wrong can be sufficiently redressed under $\mathrm{s}$. 994 to the satisfaction of the applicants (here it was clear that the applicant, Franbar, was seeking a buy-out from the majority, Casualty Plus, and the crucial issue was valuation), there is less reason for directors to subject the company to high costs of proceedings, reputational damage, and disruption to the company's activities through a derivative claim, which can easily outweigh any indirect benefits to shareholders. Attempts by courts to formulate what a hypothetical director will consider in relation to s. 172 means that judges are stepping into the shoes of directors and exercising judgment about commercial matters. This seems preferable to the alternative of courts merely subscribing to directors' commercial decisions without formulating their own views as to $\mathrm{s} .172$.

59 [2009] EWHC $2072(\mathrm{Ch})$, [2010] BCC 387 [28].

60 Franbar [2008] EWHC 1534 (Ch), [2008] BCC 885 [36].

61 Keay and Loughrey, 'Derivative Proceedings in a Brave New World' (n 39) 160. 
Stainer $v$ Lee $e^{62}$ provides a good illustration that courts are willing to exercise their judicial discretion flexibly during the two-stage procedure. Roth J was aware that the necessary evaluation of s. 263(3)(b) at this early stage of the proceedings was not mechanistic, and that a range of factors had to be considered to reach an overall view. ${ }^{63}$ There is a realistic element to s. 172 despite the notion of a hypothetical director. The views of such a hypothetical director have to be applied contextually. Here it was the loss of interest on a loan to a company (of which the defendant was the sole shareholder and director) over a long period of nine years which persuaded Roth $\mathbf{J}$ that a director would attach much importance to continuing the claim. ${ }^{64}$ It is not clear if it was the length of the failure to obtain interest or the size of the interest payment, around $£ 8.1$ million, which was ultimately persuasive. The permission to continue was however not a total victory since it was only granted until the conclusion of disclosure.

\section{(c) Observations about Sections 263(2)(a) and 263(3)(b)}

Sections 263(2)(a) and 263(3)(b) clearly involve the same considerations on many occasions as acknowledged by Lewison $\mathrm{J}$ in Franbar but they both play different roles. This must be made apparent from the outset. The key difference between these two sections is encapsulated in Iesini where s. 263(2)(a) is applicable only where the claim is obviously so weak that no director acting in accordance with s. 172 would seek to continue the claim. ${ }^{65}$ Section 263(3)(b) on the other hand will come into play where some directors would seek to continue the claim, which indicates that there is at least some material on which a hypothetical director would attach importance to. The mandatory factor is aimed at shutting out insufficiently cogent cases ${ }^{66}$ while the discretionary factor allows courts to formulate specific factors, which a hypothetical director would consider important, appropriate to each particular case so as to imbue a 'sense of reality'. ${ }^{67}$ Also, satisfying s. 263(2)(a) means

${ }^{62}$ [2010] EWHC $1539(\mathrm{Ch})$, [2011] BCC 134.

${ }^{63}$ ibid [29].

${ }^{64}$ ibid [34]-[37].

${ }^{65}$ Iesini [2009] EWHC 2526 (Ch) [86].

${ }^{66}$ Franbar [2008] EWHC 1534 (Ch), [2008] BCC 885 [30].

${ }^{67}$ HL Deb 27 February 2006, vol 679, col GC26 (Lord Goldsmith). 
automatically striking out a derivative claim without consideration of the other bars under subsection (2), while s. 263(3)(b) is analysed in conjunction with all the other non-exclusive factors set out in s. 263(3) which is a mixture of the objective and factual. ${ }^{68}$ In this respect, Gibbs was right when he said the key difference was between the other subsections under s. 263(3). ${ }^{69}$

Section 172 will clearly occupy most of the courts' time in assessing whether the mandatory or discretionary factors under sections 263(2)(a) and 263(3)(b) apply. Important issues such as the cost of proceedings, disruption to the company's activities and damage to the company will clearly be applicable across most cases. But other factors may differ on a case by case basis.

It appears that the courts will interpret s.1 72 flexibly in response to the factual demands of each case. It is clear from the above cases that identifying a discernable principle underlying s. 172 is illusory. For now, we will have to make do with the few cases and make some sense out of the court's interpretation of s. 172. But if every court were to adopt the approach in Wishart where their Lordships thought it would be unwise, at this early stage of development of the law on statutory derivative claims, to attempt to state comprehensively or definitively the approach to be followed by the court when considering an application for permission, ${ }^{70}$ then the time for certainty may never arrive. Someone has to take the first plunge. Incremental development as suggested by their Lordships in Wishart might be the easier course to take but also the slowest. It may take many more years before a substantive body of case law on the interpretation of s. 172 within ss. 263(2)(a) and 263(3)(b) is built. The courts will initially have to grapple with a lack of clarity over s. 172 until a proper footpath is built.

\section{Good Faith}

The applicant's good faith in bringing a derivative claim is one of the discretionary factors that the courts must take into account in considering

\footnotetext{
68 ibid.

69 Gibbs (n 23) 45.

${ }^{70}$ [2009] CSIH 65, 2010 SC 16 [30].
} 
whether to give permission. ${ }^{71}$ The Law Commission acknowledged that a court is unlikely to grant permission to an applicant whom it considered was acting in bad faith but regarded it as sufficiently important to be expressly stated. ${ }^{72}$ Unfortunately 'good faith' was not defined because it was assumed that the meaning was generally readily recognisable. ${ }^{73}$ This is regrettable because this may lead to uncertainty in the application of the test during the permission stage and hence "to complexity of case law. ${ }^{74}$ However, the Law Commission stated that they favoured the test of 'honestly and with no ulterior motive' although they recognised that an applicant who may benefit commercially and thus has an ulterior motive may still be considered by the courts as an appropriate person to bring the action. ${ }^{75}$ This follows the general proposition that courts wield considerable discretion in determining whether a derivative claim should proceed or not. An explicit definition may have been restrictive. Nevertheless given the courts penchant for dismissing derivative claims, it is questionable whether the court's exercise of discretion would be any better. It may be a lesser of two evils. The Law Commission considered that good faith should not be a prerequisite for leave. It now occupies some form of middle ground since it is not one of the mandatory factors but a discretionary factor that the court must take into account. Roberts and Poole were therefore correct when they opined that the applicant's good faith must have more weight than the Law Commission's view 'since it is impossible to countenance the court granting leave to an applicant exhibiting bad faith. ${ }^{76}$

Barrett $v$ Duckett ${ }^{77}$ is instructive in construing the application of good faith in Part 11. The Court of Appeal denied the applicant locus standi as she had an ulterior motive in bringing the claim, namely her personal grievances against the defendants. She was not pursuing the derivative claim bona fide on behalf of the company. In particular

71 Companies Act 2006, s.263(3)(a).

72 Law Com No. 246, para 6.75.

73 ibid, para 6.76.

74 Jill Poole and Pauline Roberts, 'Shareholder Remedies - Corporate Wrongs and the Derivative Action' [1999] Journal of Business Law 99, 107.

75 Law Com No. 246, paras 6.75-6.76

76 Poole and Roberts (n74) 107.

77 Barrett v Duckett [1995] BCC 362. 
evidence of the applicant acting partially towards her daughter by not initiating litigation against her stood against the applicant. It is submitted that the Court of Appeal came to the right conclusion as there was strong evidence that the applicant was not considering the position of the company but her own personal circumstances. However, if the good faith test were to be satisfied only in cases where there was no ulterior motive, then derivative claims would be few and far between. This was acknowledged by Sir Mervyn Davies (sitting as a High Court judge) when he said ' $[\mathrm{n}] \mathrm{o}$ doubt there is ill-feeling between [the parties] but that in itself cannot debar [the applicant], were it to do so most derivative [claims] would be frustrated. ${ }^{, 78}$ Perhaps good faith is about the honest belief of the applicant and whether the applicant has a collateral purpose that amounts to an abuse of process. This was the test favoured by Palmer $\mathbf{J}$ in the Australian case of Swansson v $R$ A Pratt Properties Pty Ltd. ${ }^{79}$ Ulterior motive or collateral purpose clearly has a role to play in the good faith test under s. 263(3)(a).

The equitable doctrine of 'clean hands' may have a role to play in assessing the applicant's good faith. Payne states that ' $[t]$ he purpose of this maxim is to prevent individuals profiting personally from their own misbehaviour. ${ }^{80}$ This is strikingly similar to the wrongdoer control rule except this time the wrongdoer is the applicant. Payne further argues that the 'clean hands' doctrine seems likely to be retained: firstly, through the courts when they take account of 'all relevant circumstances without limit' when determining whether to grant permission to continue and, secondly, through the applicant's good faith. ${ }^{81}$ The doctrine permits the defendant to raise the personal actions and circumstances of the applicant as a defence. In an unfair prejudice petition this is not at all surprising as it is a personal action. However, in a derivative claim redressing corporate wrongs, the utility this doctrine has is questionable 'since the issue for the court is doing justice to the company, and not to the shareholder, through the derivative [claim] device. ${ }^{82}$ Therefore, it is advisable that the courts

\footnotetext{
78 Barrett v Duckett [1993] BCC 778, 786.

79 (2002) NSWSC 583 [36] (Supreme Court of New South Wales).

80 Jennifer Payne, “Clean Hands” in Derivative Actions' (2002) 61 Cambridge Law Journal 76, 77.

81 ibid 80 .

82 ibid 81 .
} 
should not employ the 'clean hands' doctrine in Part 11 lest this opens a can of worms.

Lewison $\mathrm{J}$ in Iesini briefly touched on the gist of Nurcombe $v$ Nurcombe which is that 'a person may be prevented from bringing a derivative claim if he participated in the wrong of which he complains... . ${ }^{, 83}$ This suggests that where there is even an indication that an applicant who brings a derivative claim is tainted with impropriety this may work against the applicant. Does this mean an applicant has to adopt a saint-like demeanour? Keay and Loughrey suggest that Iesini points towards early signs that the 'clean hands' doctrine will re-emerge in the statutory derivative claim. ${ }^{84}$ It is unavoidable that the 'clean hands' doctrine may reappear in the new regime because good faith requires an in-depth look into the applicant's motives and conduct. This will naturally lead us to the equitable realm of 'he who comes to equity must come with clean hands.'

In Franbar, the judge refused to hold that the applicant was not acting in good faith on the grounds that the refusal to accept a buy-out of the shares did not evidence a lack of good faith. He accepted that the applicant's motive in continuing the derivative claim was to ensure that the value extracted from its shareholding would be full and fair. But that in certain cases this may not be a legitimate use of a derivative claim. However, this was a factor which was more relevant to the availability of an alternative remedy under s. 263(3)(f). ${ }^{85}$ Although the judge did not make a direct ruling as to the applicant's ulterior motive, it is clear that he was satisfied that the applicant had no improper motive.

Mission Capital shows that, provided some evidence can be shown as to why a derivative claim is useful to the company and not only to the applicant personally, then the possibility of the applicant deriving some personal benefit from the derivative claim will not necessarily mean the applicant lacks good faith. It must be shown that 'there is a real purpose in bringing the proceedings... . ${ }^{86}$ In Wishart their Lordships were aware that the question of good faith may require evidence covering the merits of the

${ }^{83}$ [2009] EWHC 2526 (Ch), [2010] BCC 420 [122].

${ }^{84}$ Keay and Loughrey, 'Derivative Proceedings in a Brave New World' (n 39) 168.

${ }^{85}$ [2008] EWHC 1534 (Ch), [2008] BCC 885 [32]-[34].

${ }^{86}$ [2008] EWHC $1339(\mathrm{Ch})$, [2008] BCC 866 [42]. 
proposed claim but they were mindful that this should not be turned into a full dress rehearsal. ${ }^{87}$ The issue of good faith can easily turn into a battle of affidavits of 'he said, she said'. To prevent this, it is proposed that evidence provided to the courts be concise and pertinent to the issue of good faith. But this often can be difficult where courts use evidence to draw inferences about the applicant's motive. In seeking to paint a bigger picture, parties may be tempted to provide as much material as possible.

The judge in Kiani $v$ Cooper ${ }^{88}$ found that withdrawal transfer of money by the applicant from the company's bank account to the applicant's personal account was not evidence of bad faith. Two factors persuaded the judge that this was not evidence of lack of good faith. Firstly, some of the monies were used to pay the company's creditors and, secondly, the monies were still in existence. ${ }^{89}$ Therefore, more good than bad had been done to the company by the withdrawal of the monies.

Allegations of lack of good faith were brought by the defendants in Stainer $v$ Lee $^{90}$ too. The defendants pointed to the fact that the applicant had sought a previous buy-out of his shares. The bringing of the derivative claim was in pursuance of the applicant's personal vendetta against the defendant for failing to offer a better price for the shares. Roth $\mathrm{J}$ was not impressed by this argument as he stated that it was entirely understandable that the applicant as a minority shareholder would seek to protect his interests. In addition, the applicant was commencing the claim on behalf of a large number of other minority shareholders. The applicant's good faith was bolstered by strong evidence of letters of support and financial contribution from thirty-five other small shareholders. ${ }^{91}$ One has to wonder whether Roth $\mathrm{J}$ would have come to the same conclusion in relation to the applicant's good faith if evidence of letters of support and financial contribution from other shareholders had not been presented. Without such evidence, it would have been difficult for the applicant to establish that the derivative claim was brought for the benefit of the company.

\footnotetext{
87 [2009] CSIH 65, 2010 SC 16 [27].

88 [2010] EWHC 577 (Ch), [2010] BCC 463.

89 ibid [36].

${ }^{90}$ [2010] EWHC 1539 (Ch), [2011] BCC 134.

91 ibid [49].
} 
Lewison $\mathbf{J}$ in Iesini said that an applicant would not be disqualified from bringing a derivative claim even if there are other benefits which the applicant would derive from the claim. ${ }^{92}$ Here the dominant purpose of the claim was to benefit the company and the existence of a collateral purpose, namely a benefit of an indemnity from a third party, did not establish a lack of good faith. This benefit was not enough to convince Lewison J that the applicant lacked good faith.

Distinguishing between a dominant purpose and collateral purpose can be a difficult exercise. This is reminiscent of the problematic principal or larger purpose exceptions in the law of financial assistance. Significant interplays between the different purposes often make it difficult to distinguish between the primary and secondary purpose. This is because disentangling the numerous strands can be evidentially difficult and even more so in allocating a relative weighting to each strand. ${ }^{93}$ The applicant's good faith test under s. 263(3)(a) is best encapsulated here by the statement of Lewison $J$ that 'if the [applicant] brings a derivative claim for the benefit of the company, he will not be disqualified from doing so if there are other benefits which he will derive from the claim. ${ }^{94}$ The main prevailing advantage of pursuing a derivative claim has to flow to the company, while any other minor associated benefits that an applicant derives will be permissible.

The discussion of the applicant's good faith in Stimpson was fudged since Judge Pelling QC was not willing to state whether the applicant's motives strictly demonstrated a lack of good faith. Instead he said that this was not material since s. 263(3) was not exhaustive of the matters that were required to be considered. The applicant's motivation in bringing the derivative claim was because he did not want the company to lose its identity or for him to lose control of the company. ${ }^{95}$ This shows that courts may find it more convenient to justify their decisions in an open manner without committing their explanations to a particular box. However, this can result in an ill-defined development of the court's jurisdiction as a consequence of protracted proceedings bringing about

\footnotetext{
92 Iesini [2009] EWHC 2526 (Ch), [2010] BCC 420 [121].

93 Hannigan and Prentice, (n 32) para 4.70.

94 Iesini [2009] EWHC 2526 (Ch), [2010] BCC 420 [121].

95 Stimpson [2009] EWHC 2072 (Ch), [2010] BCC 387 [44].
} 
ambiguity. ${ }^{96}$ Therefore, it is submitted that courts should confine their reasoning as best they can within the particular factors in s. 263(3). This ensures that practitioners are aware of which particular factor is being discussed instead of performing guesswork.

\section{Ratification}

Ratification remains pertinent to the new statutory derivative claim. It is regrettable that the Law Commission did not support reform of the substantive law on ratification. It was their view that any changes would need to be considered within a comprehensive review of directors' duties. It would not be appropriate to make piecemeal changes within the reform of shareholder remedies which may have wider implications. ${ }^{97}$ However, there should have been an overhaul of the law on ratification considering the closeness between derivative claims and ratification through the principle of 'majority rule'. The courts will generally not entertain claims brought by the minority in relation to matters which the majority can decide because what will happen is that 'a meeting has to be called, and then ultimately the majority gets it wishes. ${ }^{98}$ 'Majority rule' remains an established principle of company law and a central theme underlying ratification.

It is likely that issues which plagued the derivative claim in common law will reappear in the new regime as questions about whether ratification has been effective and ratifiability will retain importance. Some commentators have suggested that the effectiveness of a purported ratification "will reintroduce pleadings similar to those necessary under the [common] law, ${ }^{99}$ which "will dominate the hearing for leave and... [are] unlikely to result in a change of emphasis. ${ }^{100}$ This suggests that the issue of 'effective ratification' will detract the court from focusing on other areas as they are too busy addressing the effectiveness of a purported ratification. Besides this, ratifiability is to be taken into account by the courts as one of the discretionary hurdles under s. 263(3)(c)(ii).

\footnotetext{
96 Keay and Loughrey, 'Derivative Proceedings in a Brave New World' (n 39) 168.

97 Law Com No. 246, para 6.85.

${ }^{98}$ MacDougall v Gardiner (1875) 1 Ch D 13 (CA) 25.

${ }^{99}$ Poole and Roberts (n74) 109.

${ }^{100}$ Lowry and Reisberg (n 48) 234.
} 
Although ratifiability is no longer a complete bar to a derivative claim, it is likely that the courts will order an adjournment of the permission hearing to consider whether the wrong will be ratified by the company in a meeting. Excessive use of adjournments may suggest a policy of encouraging internal solutions while discouraging derivative claims.

One of the crucial changes to ratification is in relation to voting since s. 239 now provides that the votes of wrongdoing directors and connected members will be disregarded in ratifying such wrongdoing conduct. This reverses the decision in North West Transportation Co Ltd v Beatty. ${ }^{101}$ This change is welcomed since wrongdoers should not be able to use their voting powers to ratify a wrong in which they participated, as their decision will clearly be tainted by bias and impropriety.

So far only two cases have properly considered the issue of ratification - Franbar and Stainer v Lee. In Franbar, William Trower QC stated that the 'connected person' provisions in ss. 239(3) and 239(4) impose additional requirements for effective ratification which draw on existing equitable rules but which impose more stringent demands. Furthermore, 'wrongdoer control' remains relevant to ratification in cases where the 'connected persons' provision in s. 239(4) has not been satisfied. ${ }^{102}$ Arguably his intention was to capture those situations where s. 239(4) has not been satisfied but actual 'wrongdoer control' exists, the wrongdoers should not then be able to ratify their wrongdoing by utilising a 'loophole' in the statutory derivative claim.

The concept of 'wrongdoer control' which the Law Commission had been so keen to remove has now crept back in. 'Wrongdoer control' was concerned with standing. It is not clear why wrongdoer control should be reintroduced to the statutory derivative claim since the mandatory and discretionary factors under ss. 263(2) and 263(3) are adequate screening mechanisms in determining permission. $\mathrm{Mr}$ Trower's statement emphasises the relevance of ratification and non-ratifiable breaches in Part 11 as it was in common law. Thus, questions regarding reconciliation

101 (1887) LR 12 App Cas 589.

${ }^{102}$ Franbar [2008] EWHC 1534 (Ch), [2008] BCC 885 [44]-[45]. 
of the conflicting cases of Cook $v$ Deeks ${ }^{103}$ and Regal (Hastings) Ltd $v$ Gulliver ${ }^{104}$ will inherently arise in the new regime.

Yap argues that in light of the s. 239 element of disinterested shareholders' approval in ratification, 'there appears to be much less reason to require the courts to scrutinize the nature of the transaction to see if it falls within the hazy ambit of the principle of non-ratifiable breaches. ${ }^{105}$ This would certainly be welcomed in terms of avoiding the issue of whether English law adopts the transaction-based theory or voting-based theory of ratification since such uncertainty is capable of lengthening and complicating the two-stage procedure. There seems to be a shift towards a voting-based theory following the introduction of the new connected persons/disinterested shareholder's provision in s. $239 .{ }^{106}$

This may bring forth issues such as vote counting and identification of connected persons. This may be fairly easy to comply within a small company but in large public companies that tend to vote by proxy this matter is less straightforward. In Prudential Assurance Co Ltd v Newman Industries ${ }^{107}$, Vinelott $\mathrm{J}$ in first instance observed that in a large company the wrongdoing directors 'might be able to determine the outcome of a resolution in general meeting in their own favour by the use of proxy votes.' 108 Furthermore, it is challenging to unravel the often intricate 'shareholding linkages' in large companies, which makes it difficult to identify particular shareholders who may be influenced in the way they vote by the wrongdoers, their nominees, relatives and friends. ${ }^{109}$ This makes the breadth of the 'connected persons' provision potentially very wide; identifying shareholders' motivation in voting can be elusive. Despite these practical difficulties, a voting-based approach seems preferable than attempting to determine ahead the types of wrongs that are

\footnotetext{
${ }^{103}$ Cookv Deeks [1916] 1 AC 554 (PC).

${ }^{104}$ Regal (Hastings) Ltd v Gulliver [1967] 2 AC 134 (HL).

105 Ji Lian Yap, 'Reforming Ratification' (2011) 40 Common Law World Review 1, 10.

${ }^{106}$ Companies Act 2006, s.239 should be read together with s. 252 to determine the meaning of 'connected persons'.

107 [1981] Ch 257.

108 ibid 324.

${ }^{109}$ Pearlie Koh, 'Directors' Fiduciary Duties: Unthreading the Joints of Shareholder Ratification' (2005) 5 Journal of Corporate Law Studies 363, 389.
} 
or may possibly be in the company's interests. ${ }^{110}$ The factual circumstances of each case differ and to assume that a particular category of transaction is applicable across the board is simplistic. Furthermore, Payne argues that a transaction-based approach exacerbates the difficulties in ratification, and the better approach is to determine whether shareholders are acting contrary to the interests of the company rather than attempting to extrapolate information from the circumstances surrounding the wrongdoing. ${ }^{111}$ This resembles the approach of Part 11, albeit the courts do not have to fully assess whether shareholders are voting in the best interests of the company, or look at their individual motivations. The courts simply have to examine ss. 249 and 252.

In Stainer $v$ Lee, Roth J was concerned with the question of informed consent. He was not satisfied that the shareholders voting by proxy in favour of the resolution approving the new loan agreement could be said to have given informed consent: ${ }^{112}$ the notice giving information did not satisfy the principles of fair disclosure of the purpose for which the meeting was convened, ${ }^{113}$ and that a notice must contain the contents of the agreement. ${ }^{114}$ This case highlights that the issue of 'fully informed consent' remains relevant to ratification. This may lead to protracted permission hearings since determining whether there has been 'fully informed consent' will inevitably lead the courts to an extensive evidentiary analysis of documentation.

Contrary to the gloomy predictions of many commentators, ratification has not become a colossal battleground in the new statutory derivative claim (as yet). Also, it has not become a technique frequently employed by wrongdoing directors or controlling shareholders to restrain a derivative claim. ${ }^{115}$ However, the fact that effective ratification will bar

${ }^{110}$ Hans C. Hirt, 'Ratification of Breaches of Directors' Duties: the Implications of the Reform Proposal regarding the Availability of Derivative Actions' (2004) 25 Company Lawyer 197, 205.

111 Jennifer Payne, 'A Re-examination of Ratification' (1999) 58 Cambridge Law Journal 604, 615.

112 Stainer v Lee [2010] EWHC 1539 (Ch), [2011] BCC 134 [46].

113 Kaye v Croydon Tramways Co [1898] 1 Ch 358.

114 Pacific Coast Coal Mines Ltd v Arbuthnot [1917] AC 607.

115 Paul Von Nessen, S. H. Goo and Chee Keong Low, 'The Statutory Derivative Action: Now Showing Near You' [2008] Journal of Business Law 627, 661. 
a claim under s. 263(2)(c)(ii) may have led to a dwindling of the already small numbers of derivative claims. Not many lawyers (except unscrupulous ones) would advice their client to pursue a derivative claim having ascertained the existence of effective ratification. Despite ratification only being properly considered in two cases to date, future case law will be able to provide a better indication as to whether the 'minimalist' approach adopted by the Law Commission to ratification will significantly attenuate the value of their work in constructing a new derivative claim. ${ }^{116}$ The two cases above have shown that the concept of wrongdoer control, non-ratifiable breaches and fully informed consent may re-emerge in the new regime. Thus, it is regrettable that there was no overhaul of the substantive law of ratification during the reform process. The better route would have been to remove 'effective' ratification as a complete bar in the new statutory derivative claim as is the case in Australia, Hong Kong, Singapore, South Africa and Canada. This would have removed uncertainties and inconsistencies in the law of ratification so that the statutory derivative claim could truly deliver 'modern, flexible and accessible criteria. ${ }^{117}$

\section{INDEMNITY COSTS ORDERS}

Financial considerations will usually be the first factor which informs a shareholder as to whether it is worth pursuing a derivative claim. Regardless of how strong a claim and aggrieved a shareholder, this is negligible without a strong financial footing for shareholders to pursue a derivative claim. Indemnity costs orders have been assumed to be the answer to providing financial incentives to shareholders. Therefore, no change was made to the court's power to make indemnity costs orders in derivative claims. ${ }^{118}$ This has been criticised as leaving the derivative claim with a missing crucial procedure ${ }^{119}$ and rightly so. There were surprisingly even concerns that indemnity costs orders would create an

${ }^{116}$ Anthony J. Boyle, Minority Shareholders' Remedies (Cambridge University Press 2002) 77.

${ }^{117}$ Law Com No. 246, para 6.15.

${ }^{118}$ Law Com No. 142, para 17.8.

${ }^{119}$ Mahmoud Almadani, 'Derivative Actions: does the Companies Act 2006 Offer a Way Forward?’ (2009) 30 Company Lawyer 131, 138. 
additional incentive for some individuals to initiate unmeritorious and frivolous claim. ${ }^{120}$ This misplaced notion was likely encouraged by the Law Commission's view that there is a compelling reason to pursue a derivative claim because of the possibility of an indemnity costs order. ${ }^{121}$ This misses the crucial point that indemnity costs orders are not automatic rights or generously granted. So a claimant will potentially be exposed to significant costs since he or she cannot be certain as to whether the court will exercise its discretionary powers to grant an indemnity costs order. ${ }^{122}$ Without prospective certainty as to whether the courts will order the company to pay the shareholders' costs of litigation, shareholders may be deterred from pursuing a derivative claim. Furthermore, shareholders may be at risk of paying litigation expenses as well as the legal expenses of the defendant if the claim is unsuccessful. The use of derivative claims will rarely be rational in light of this deadly mix of financial disincentives. ${ }^{123}$ Reducing costs is therefore crucial in overhauling the derivative claim and increasing the paucity of litigation.

Wallersteiner $v$ Moir (No. 2) ${ }^{124}$ is authority for the proposition that a shareholder who brings a derivative claim may be indemnified by the company in respect of costs the shareholder has incurred, even if the claim should fail, provided the shareholder acted in good faith and on reasonable grounds. ${ }^{125}$ Further, it was held in Smith $v$ Croft $(\text { No. } 1)^{126}$ that claimants applying for a costs indemnity order must show that it is genuinely needed, ${ }^{127}$ and it may be appropriate to leave a proportion of the costs to the claimants to spur them on to proceed with the claim. ${ }^{128}$ Indemnity costs orders are provided for under the Civil Procedure Rules, which state that ' $[t]$ he court may order the company ... to indemnify the claimant against liability for costs incurred in the permission application

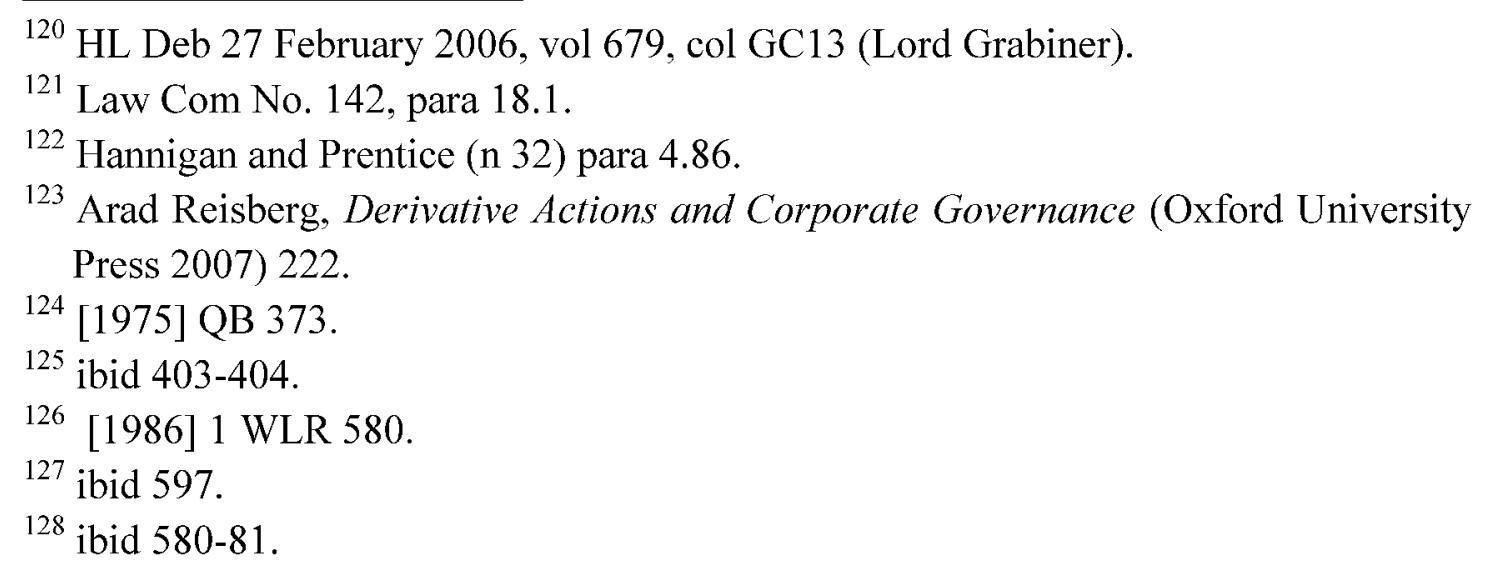


or in the derivative claim or both. ${ }^{129}$ The ruling by the court in Smith $v$ Croft (No. 1) was not followed by Lewison $\mathrm{J}$ in Iesini as he preferred to adopt the view of Michael Wheeler QC in Jaybird Group Limited $v$ Wood $^{130}$ that indemnity costs orders are not limited to impecunious claimants. ${ }^{131}$ This view is preferable since the benefit of any remedy accrues to the company and it should not matter how wealthy an applicant is. There may be borderline cases where the applicant is deemed sufficiently well-off so as not to be granted indemnity costs during the permission stage. Nevertheless should the claim be protracted in nature, costs will mount up and the claimant may be faced with an uphill task of obtaining sufficient funds for the remaining stages. The applicant could possibly seek a further order for indemnity costs as this is fully within the discretion of the courts under CPR 19.9E.

Recent cases highlight that the courts have taken a fairly pragmatic stance to indemnity costs orders. In Kiani $v$ Cooper, Proudman J made a limited indemnity costs order in favour of the applicant but not in respect of any adverse costs order. He further commented that the applicant should assume part of the risk of litigation. ${ }^{132}$ This is similar to the principle in Smith v Croft (No. 1) where it was held that some proportion of the costs should be borne by the claimants to spur the claim on. It can be clearly seen that this area remains a delicate balancing exercise for courts. Courts should not be too generous in granting indemnity costs orders because of the likelihood of opening a floodgate of claims, and yet they cannot be too severe in their approach since this may hinder genuine derivative claims from being pursued.

Roth $\mathrm{J}$ in Stainer $v$ Lee adopted a slightly more permissive interpretation when he stated that Wallersteiner v Moir (No. 2) is clear authority that a shareholder who is granted permission to continue should normally be indemnified as to such reasonable costs by the company for whose benefit the claim is taken. ${ }^{133}$ However, he then placed a ceiling on prospective indemnity costs at a $£ 40,000$ limit but with permission to

\footnotetext{
${ }^{129}$ Civil Procedure Rules 1998, 19.9E.

${ }^{130}$ Jaybird Group Limited v Wood [1986] BCLC 319, 327.

131 [2009] EWHC 2526 (Ch), [2010] BCC 420 [125].

${ }^{132}$ Kiani v Cooper [2010] EWHC 577 (Ch), [2010] BCC 463 [49].

133 Stainer v Lee [2010] EWHC 1539 (Ch), [2011] BCC 134 [56].
} 
apply for extension. It was felt that the applicant's costs could become disproportionate where the amount of likely recovery was presently uncertain. ${ }^{134}$ Is this striking the right balance? Roth $\mathrm{J}$ was not closing the door towards an extension and the possibility of further indemnity costs should be a sufficient incentive for applicants. This approach allows courts to monitor the progress of the claim at every stage while reassessing the adequacy of indemnity costs as appropriate to the particular circumstances. Such a practical approach seems to strike the right balance in enabling shareholders to bring derivative claims without being a significant drain on their personal finances.

Wishart provides a more thorough discussion of indemnity costs orders and shows the courts' cautious approach. Their Lordships preferred to allow the law on this matter to develop incrementally instead of stating comprehensively or definitively the approach which should be followed. ${ }^{135}$ How far their approach will be followed by the English courts will have to be seen since the court made it abundantly clear that their observations were based on the present circumstances and submissions which were made in the case. Their Lordships considered that the appropriateness of an indemnity should be determined in the leave proceedings (i.e., the permission stage in England and Wales) rather than at the substantive hearing. ${ }^{136}$ This has been followed in the above cases of Iesini, Kiani v Cooper and Stainer $v$ Lee. This approach is advantageous to applicants. They are given a degree of certainty early on during the permission stage before truly committing themselves to the cause, which by then may be too late for them as the costs incurred may be substantial.

In Wishart their Lordships also stated that the terms of an indemnity costs order "should reflect the fact that there is a limit to the extent to which the court can assess, in advance, the reasonableness of [the applicant] having incurred any particular liability or expense. ${ }^{137}$ Both the judges in Kiani v Cooper and Stainer $v$ Lee placed a limit to indemnity costs whether by way of confining indemnity costs to all costs except adverse costs orders or an imposition of a ceiling on costs. This is in

\footnotetext{
134 ibid.

135 Wishart [2009] CSIH 65, 2010 SC 16 [49].

136 ibid [62].

137 ibid [68].
} 
keeping with the foregoing statement in Wishart about the dangers of the court's writing a blank cheque for the shareholder as to the amount of expenses that can be incurred in the derivative proceeding. ${ }^{138}$

The seemingly generous attitude of the courts to granting prospective indemnity costs orders is considerably weakened by a countervailing reluctance by the courts to be decisive. Without being unnecessarily restrictive in refusing to grant a prospective indemnity costs order during the permission stage because of difficulties with quantifying liabilities and expenses, the courts in Kiani $v$ Cooper and Stainer $v$ Lee have instead taken a pragmatic approach. The courts appreciate that indemnity costs orders can be granted up to a specified stage and with permission to apply for extension once a further stage has been reached. Although the courts in the above cases did not explicitly endorse the ruling in Wishart, it is clear that the approach in Wishart was followed. This is a further indication that indemnity costs orders will not be the panacea for remedying the funding worries of shareholders but at least remains a possible resource.

\section{E. Pursuing Corporate Relief in Unfair Prejudice Petitions}

The possibility of pursuing corporate relief in unfair prejudice petitions has expanded the use of s. 994 while simultaneously relegating the statutory derivative claim to the sidelines. In Re Charnley Davies Ltd (No. 2), ${ }^{139}$ Lord Millett provided guidance as to the relationship between derivative and personal claims in relation to unfair prejudice, which is essentially that a misconduct claim lies with a derivative claim, while wider instances of conduct requiring a broader remedy lie with the unfair prejudice petition. ${ }^{140}$ Thus, it was well-established that a minority shareholder pursuing a corporate remedy does so by way of a derivative claim while seeking an unfair prejudice petition for a personal remedy. However, in Re Saul D Harrison \& Sons plc, ${ }^{141}$ Hoffmann LJ equally made it clear that "[e]nabling the court in an appropriate case to outflank the rule in Foss $v$ Harbottle was one of the purposes of [CA 2006, s.

\footnotetext{
138 ibid.

${ }^{139}$ Re Charnley Davies Ltd (No. 2) [1990] BCC 605.

140 ibid 625.

141 [1994] BCC 475.
} 
994]. ${ }^{142}$ Judicial flexibility meant that in particular circumstances s. 994 (then s. 459) petitions could be used even though a derivative claim, being the more appropriate action, was unavailable due to the restrictive rules in Foss $v$ Harbottle. The breadth of protection under the unfair prejudice petition makes it an extremely attractive remedy for minority shareholders. Courts have interpreted s. 994 flexibly which is in direct contrast to the cautious and restrictive interpretation of derivative claims. Perhaps this bolder approach has been partly spurred on by the wording of s. 996 that grants a court wide discretion to "make such order as it thinks fit for giving relief' This has played a substantial role in elevating unfair prejudice petitions as the remedy of choice of most minority shareholders, particularly in small private companies.

The recent cases of Clark $v$ Cutland ${ }^{143}$ and Gamlestaden Fastigheter $A B v$ Baltic Partners $L t d^{144}$ highlight the courts' concessionary attitude in granting corporate relief in unfair prejudice petitions. In Clarkv Cutland, the Court of Appeal granted corporate relief to the company on the unfair prejudice petition. The use of s. 996 in this way does approximate the solution suggested by Lowry of broadening the relief provided by s. 996 to include the power to direct that profits and damages be accounted in favour of the company itself. ${ }^{145}$ However, what Lowry was suggesting was an established statutory basis for such relief and not judicial decisionmaking. As a reminder, the claimant in Clark v Cutland had commenced both a derivative claim and unfair prejudice petition against the defendant which were subsequently consolidated. This was not a pure unfair prejudice petition but a claim which involved elements of unfairly prejudicial conduct and misconduct more appropriate to derivative claims. This liberal attitude towards using the unfair prejudice petition to grant corporate relief is reminiscent to the case of Lowe $v$ Fahey. ${ }^{146}$ There it was held that s. 461 (now s. 996) conferred a wide jurisdiction, which meant a petitioner was entitled to seek an order that those involved in the unlawful diversion provide for payment to the company itself in circumstances

\footnotetext{
142 ibid 489.

143 [2003] EWCA Civ 810, [2004] 1 WLR 783.

144 [2007] UKPC 26, [2007] Bus LR 1521.

145 John Lowry, 'Reconstructing Shareholder Actions: a Response to the Law Commission's Consultation Paper' (1997) 18 Company Lawyer 247, 255.

${ }^{146}$ [1996] BCC 320.
} 
where the unfairly prejudicial conduct involved wrongful diversion of funds. ${ }^{147}$

These cases show that, prior to corporate relief being granted on an unfair prejudice petition, there must have been mixed grounds comprising unfairly prejudicial conduct and corporate misconduct. This at least provides for the statutory derivative claim retaining some usefulness in cases where the only ground is a corporate wrong since it is apparent that an action must be commenced as a derivative claim if the only ground for petition rests on a corporate wrong. ${ }^{148}$ However, it is not difficult to envisage circumstances where ingenious lawyers can 'conjure up' the existence of unfairly prejudicial conduct even in clear-cut cases of corporate wrongs. Past cases have shown that courts have been rather generous in accepting that breaches of directors' duties are capable of establishing unfairly prejudicial conduct. For instance in Re a Company (No. 008699 of 1985) ${ }^{149}$ the directors of the company provided advice as to the acceptance of competing bids. It was held that this was potentially a breach of the directors' fiduciary duties and could constitute unfairly prejudicial conduct. ${ }^{150}$ The flexibility of the court's approach to assessing the existence of unfairly prejudicial conduct is a result of their jurisdiction under s. 994 which has 'an elastic quality which enables the courts to mould the concepts of unfair prejudice according to the circumstances of the case. ${ }^{, 151}$

The Privy Council decision in Gamlestaden is likely to provide further support that an unfair prejudice petition can be used to provide corporate relief. Lord Scott of Foscote held that the wide language of the unfair prejudice provisions allowed for the Privy Council's jurisdiction to grant an order for payment of damages to the company. ${ }^{152}$ Surprisingly no reference was made to Lord Scott's previous judgment in Re Chime Corp $L t d^{153}$ where he laid down two criteria which should be satisfied by the petitioner, namely (1) that the order for payment to be made by a

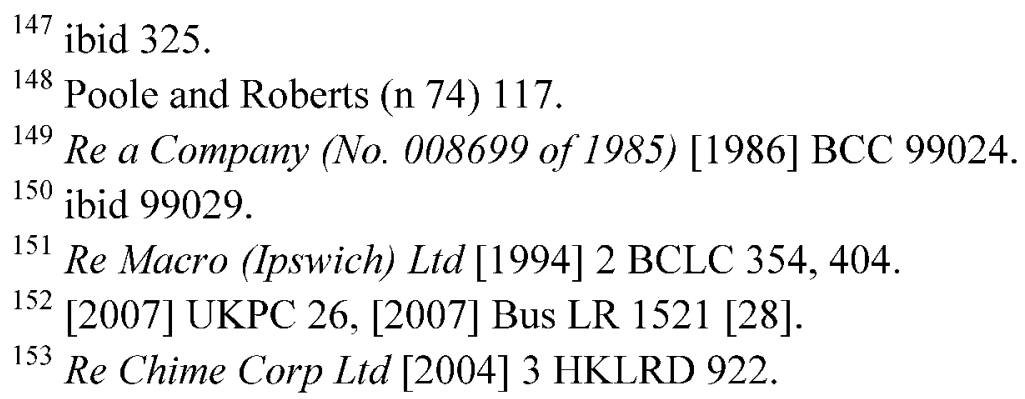


respondent to the company corresponds with the order to which the company would have been entitled had it sued or if a derivative claim had been made; and (2) that it is clear at the pleading stage that a determination of the amount, if any, of the director's liability at law to the company can conveniently be dealt with in the hearing of the petition. ${ }^{154}$ Having passed up the opportunity to confirm or clarify the criteria specified in Re Chime Corp Ltd, it is regrettable that Lord Scott did not provide further guidance as to when the court's power under s. 994 to make a corporate remedy should be exercised. However, Cheung questions whether the restatement in Gamlestaden without reference to the criteria is an 'accurate summary of principles' derived from Lord Scott's earlier judgment in Re Chime. ${ }^{155}$ But without more and simply on the reading of Lord Scott's judgment in Gamlestaden, there is a strong indication that an unfair prejudice petition can be used to obtain corporate relief without satisfying the two criteria.

Payne suggests that s. 994 petitions will effectively supersede derivative claims in the future, ${ }^{156}$ while Hannigan believes Clark $v$ Cutland and Gamlestaden are in reality very limited and that fundamentally they are classic derivative claims, not unfairly prejudicial cases at all. ${ }^{157}$ The consolidation of the derivative claim and unfair prejudice petition in Clark $v$ Cutland should not detract from the fact that that the Court of Appeal treated the unfair prejudice petition as if it were a derivative claim, and as stated by Arden LJ 'it was in the [unfair prejudice] proceedings that relief was ultimately granted. ${ }^{158}$ The unfair prejudice petition was ultimately the decisive jurisdiction in which corporate relief was granted. The views expressed by Payne are likely to be realised in the future as Clark $v$ Cutland and Gamlestaden represent a novel but legitimate interpretation of the breadth of protection under s. 996. This is coupled with (1) the absence of a restrictive permission stage in s. 996

\footnotetext{
154 ibid [62].

155 Rita Cheung, Company Law and Shareholders' Rights (LexisNexis Butterworths 2010) 289.

156 Jennifer Payne, 'Sections 459-461 Companies Act 1985 in Flux: the Future of Shareholder Protection' (2005) 64 Cambridge Law Journal 647, 676.

${ }^{157}$ Brenda Hannigan, 'Drawing Boundaries between Derivative Claims and Unfairly Prejudicial Petitions' [2009] Journal of Business Law 606, 623-24.

158 [2003] EWCA Civ 810, [2004] 1 WLR 783 [2].
} 
petitions, (2) the advantages of obtaining direct personal remedies and corporate remedies under s. 996, and (3) ratification not being a bar to an unfair prejudice petition. The possibility of indemnity costs orders in derivative claims may shift the scale slightly away from unfair prejudice. But as examined above, the indemnity costs order do not provide a strong enough financial incentive for shareholders to pursue derivative claims. On balance, the unfair prejudice remedy will remain the 'remedy of choice among shareholders. ${ }^{159}$

\section{F. CONCLUSION}

The restrictive standing requirements in Foss $v$ Harbottle have in effect been replaced by judicial control over the streamlined list of factors under Part 11. The approach of the courts to these factors in practice has so far been unclear due to their refusal in making a committed standpoint to the factors being considered. Such uncertainty has left a void in terms of predicting the outcome of a derivative claim. Furthermore, Wishart is a reminder that the courts prefer incremental development. For now we can only make an educated guess as to how courts will construe factors such as the prima facie case, good faith, s. 172 and ratification in practice. Previous case law provides significant but limited assistance as the new regime provides courts with a wide discretion to interpret the factors in a different manner.

Recent cases do however show that concepts or tests which existed in common law such as prima facie, good faith and ratification have been interpreted so as to stay close to their origins. These are factors which do not pose as much concern to practitioners as the new s. 172 terminology. Recent case law has shown that the bulk of the courts' reasoning have been dedicated to s. 172. Nevertheless it is far from clear as to how courts in future cases will construe s. 172 and waiting for a substantive body of case law to be built will be agonising. The new statutory derivative claim was meant to deliver a 'more modern, flexible and accessible criteria for determining whether a shareholder should be able to pursue the action., 160

But the uncertainty that presently exists has led to vague and inaccessible criteria. Furthermore, whatever procedural benefits provided

\footnotetext{
${ }^{159}$ Cheffins (n 15) 259.

${ }^{160}$ Law Com No. 246, para 6.15.
} 
by Part 11 will be insignificant in light of the approach to indemnity costs orders and the possibility of obtaining corporate relief in unfair prejudice petitions. Providing sufficient financial incentive is the key to building up the statutory derivative claim but the court's limited approach to indemnity costs orders has not provided the catalyst for pursuing derivative claims. This was probably the intended result. With the growing attractiveness of the unfair prejudice remedy, one can only wonder whether the derivative claim has any role to play in the arsenal of shareholder remedies. For now at least, the costs of pursuing a derivative claim outweigh its benefits (if any). Until a more definitive guideline for the list of factors in the two-stage procedure is provided by the courts and a bold approach is taken to granting indemnity costs orders, the demise of the derivative claim seems inevitable. 